\title{
Die (Ohn-) Macht der "Mitte". Zur gesellschaftlichen Position bürgerlicher Schichten in Kleinstädten
}

\begin{abstract}
Der Beitrag beschäftigt sich mit den Veränderungen der sozialen, wirtschaftlichen und politischen Lebensumstände niederösterreichischer bürgerlicher Schichten im I9. Jahrhundert. Er knüpft an die Befunde der seit den I98oer Jahren etablierten Forschung zum Bürgertum Niederösterreichs bzw. der Habsburgermonarchie an und stellt in Anlehnung an die „Neue Politikgeschichte“ die Funktion und die Konsequenzen der Idee „Mittelstand“ in den Vordergrund. Anhand reichen statistischen Materials kommen auch die sozioökonomischen Grundlagen bürgerlichen Lebens in einer Zeit des Umbruchs zur Sprache; eines Umbruchs, der einerseits bildungshungrigen und geschäftstüchtigen Bürgerlichen Chancen des Aufstiegs eröffnete, andererseits für das traditionelle Wirtschaftsbürgertum einen Verlust an Status und sozialer Sicherheit bedeutete. Der Beitrag argumentiert die Idee „Mittelstand“ als eine spezifische Wahrnehmung der sozioökonomischen Realität. Sie formte Interpretationen, die in politische Strategien überführt wurden. Dies erlaubte, Vorstellungen einer idealen Gesellschaft zu artikulieren und die Verteilung von gesellschaftlichen Ressourcen im Sinne des „Mittelstandes“ zu beeinflussen.
\end{abstract}

The Powerful/Powerless Middle Class. The Social Standing of the Middle Class in Towns. This chapter focuses on the consequences of social, economic and political change affecting the life circumstances of the Lower Austrian middle classes during the $19^{\text {th }}$ century. Connecting to the well-established research field of the bourgeois history of Lower Austria and the Habsburg Monarchy, the article takes up the New Political Sciences' approach of focusing on the political impact of ideas to analyse the function and the consequences of the popular concept of the "middle class". The economic consequences of liberalism and industrialisation on middle-class livelihoods are also discussed on the basis of rich statistical material. While producing opportunities and wealth for those eager to be educated and making their way in the industrial sector, modern times threatened the social and economic status of the traditionalist petty bourgeoisie. The idea of the "middle class" provided those confused by social and economic change with interpretations and strategies with which to articulate concepts of an ideal society and influence the distribution of resources accordingly.

Keywords: political ideas, discourse analysis, inequality, collective identity

doi.org/10.52035/noil.2021.19jh02.06

Veröffentlicht nach externer Begutachtung (doppelblind) / published after external peer review (double blind) 